\title{
Fertilization in Butia odorata seedlings formation
}

\author{
Fertilización en la formación de plantas de Butia odorata
}

\author{
Claudimar Sidnei Fior a, Luciana Pinto Paim a, Monique Caumo a, \\ Luciano da Silva Alves ${ }^{a *}$, Sérgio Francisco Schwarz ${ }^{a}$

\begin{abstract}
*Corresponding author: ${ }^{\text {a }}$ Universidade Federal do Rio Grande do Sul, Faculdade de Agronomia, Departamento de Horticultura e Silvicultura, Avenida Bento Gonçalves, 7712, Porto Alegre, Rio Grande do Sul, Brazil, tel.: +55051 984651583, luciano.alves@ufrgs.br
\end{abstract}

\begin{abstract}
SUMMARY
Butia odorata is an endangered palm tree native of southern Brazil and Uruguay with great food and ornamental potential. The lack of phytotechnical information hinders the commercial production of their seedlings. The aim of this work was to test doses of fertilization on the formation of $B$. odorata seedlings and tolerance to salinity levels in the substrate. The seedlings were cultivated in containers, submitted to control and four doses of fertilizer per liter of substrate. We evaluated stem diameter, number of leaves and pinnate leaves, electrical conductivity (EC) and $\mathrm{pH}$ of the substrate. The experimental design was in random blocks with 10 plants per treatment. Dry density, air space, and total pore space of the substrate were within the ideal ranges, such as EC and $\mathrm{pH}$, without a significant trend for these last two variables in relation to the doses of fertilizers. Throughout the experiment, the $\mathrm{pH}$ remained adequate, except for higher dosage treatments that acidified the substrate. EC increased gradually, except for control treatment. There was a significant difference between treatments and blocks for plant variables, with the second access plants presenting larger stem diameter. The dosages that induced higher responses were 0.6 and $1.2 \mathrm{~g} \mathrm{~L}^{-1}$ with EC corresponding to $5 \mathrm{mS} \mathrm{cm}^{-1}$, which is possibly the limit of salts in the substrate tolerated by the species. B. odorata responded positively to the fertilization during the formation of the seedlings. However, until the juvenile phase, its development is impaired if EC reaches $5 \mathrm{mS} \mathrm{cm}^{-1}$.
\end{abstract}

Key words: Arecaceae, native species, propagation.

\section{RESUMEN}

Butia odorata es una palmera en peligro de extinción originaria del sur de Brasil y Uruguay con gran potencial alimenticio y ornamental. La falta de información fitotécnica dificulta la producción comercial de sus plantas. El objetivo de este trabajo fue evaluar fertilización en la formación de plantas de B. odorata y su tolerancia a la salinidad del sustrato. Las plantas se cultivaron en contenedores, sometidas a control y cinco dosis de fertilizante. Fueron evaluados: diámetro del tallo, número de hojas y hojas pinnadas, conductividad eléctrica (EC) y pH del sustrato. El diseño experimental fue en bloques aleatorizado con 10 plantas por tratamiento. La densidad aparente, el espacio de aire y el volumen total de poros del substrato estuvieron dentro de rangos ideales; también la EC y el pH, sin tendencia significativa para estas dos últimas variables en relación con las dosis de fertilizantes. El pH se mantuvo adecuado, excepto con dosis más altas que acidificaron el sustrato. La EC aumentó gradualmente, excepto para el tratamiento de control. Hubo diferencia significativa entre tratamientos y bloques para las variables de la planta. Las dosis que indujeron respuestas mayores fueron 0,6 y $1,2 \mathrm{~g} \mathrm{~L}^{-1}$ con EC de $5 \mathrm{mS} \mathrm{cm}^{-1}$, que es posiblemente el límite de sales en el sustrato tolerado por la especie. Butia odorata respondió positivamente a la fertilización durante la formación de las plantas. Sin embargo, hasta la fase juvenil, su desarrollo se vio afectado cuando la EC alcanzó $5 \mathrm{mS} \mathrm{cm}^{-1}$.

Palabras clave: Arecaceae, especies nativas, propagación.

\section{INTRODUCTION}

Butia odorata (Barb. Rodr.) Noblick, commonly known as "butiazeiro", is a species of the Arecaceae family, native from Uruguay and southern Brazil, where it occurs only in Rio Grande do Sul State (Soares et al. 2014). Besides these sites, the genus Butia occurs in Argentina and Paraguay, where it grows in different types of environments, such as grassland formations and Restinga vegetation and is asso- ciated with areas under full sun or little shade (Geymonat and Rocha 2009, Lorenzi et al. 2010).

The species $B$. odorata is a palm tree of 2 to $8 \mathrm{~m}$ of height, with pistil flowers and elliptical fruits (Deble et al. 2011) widely used in food, mainly in the production of sweets, ice cream and beverages (Büttow et al. 2009, Barbieri et al. 2014). Besides, the species can be used for recovery and restoration of degraded areas, for filling and enriching diversity since it is attractive to seed dispersers, 
and classified as heliophile, which allows its use without the need for shading. Similarly, the species can be used in landscaping due to its beauty and in the manufacture of handmade products from its leaves and pyrenes. The natural occurrence of the genus Butia is associated with environments possessing high diversity of fauna and flora, called 'butiazais' or 'palmares', where the individuals are distributed in aggregate populations (Marcato 2004, Paim and Paim 2016, Marchi et al. 2018). It is also worth mentioning the tolerance of these species to low temperatures, where $B$. odorata is a typical example, since its distribution limit reaches the austral zone, in other words, in regions of subtropical climate through the Pampa biome (Schlindwein 2012).

However, despite the social, economic and biological importance, all species of the genus Butia that occur in Rio Grande do Sul State are threatened (Rio Grande do Sul 2014), mainly due to the advance of agricultural frontiers, urbanization, forestry monocultures and livestock farming (Barbieri et al. 2015). Although livestock production is considered a vocation of Pampa biome, the activity hinders the process of natural regeneration and, consequently, the renewal of the butiazais, since its dissemination occurs only through seeds for this species and the new seedlings are subject to trampling and consumption by the animals (Geymonat and Rocha 2009, Rivas and Barbieri 2014).

According to Geymonat and Rocha (2009), the commercial production of seedlings of $B$. odorata is hampered by slow and uneven germination. Likewise, the information available on the formation of seedlings of the species is scarce and incomplete, including some considerations about cultivation in containers using substrate with good drainage, medium fertility and neutral $\mathrm{pH}$. Therefore, this study tests the hypothesis that the development and improvement of methods related to the conditions of $B$. odorata seedling formation can satisfy the demand for quality seedlings. The aim of this work is to test doses of fertilization on the formation of $B$. odorata seedlings and the tolerance of plants to salinity levels in the substrate.

\section{METHODS}

The present work was developed with seedlings obtained from seeds of mature fruits of $B$. odorata, collected in situ in two sites (accesses): the first in Encruzilhada do Sul/ RS (ten parent plants) and the second in Santa Vitória do Palmar/RS (five parent plants). After collection, the fruits were transferred to the Biotechnology Laboratory of the Department of Horticulture and Forestry of the Federal University of Rio Grande do Sul, in Porto Alegre/RS and pulped by manual friction in metallic sieves with a $5-\mathrm{mm}$ mesh under running water. The pyrenes (endocarps of seeds) were dried on filter paper in the laboratory $\left(\sim 25^{\circ} \mathrm{C}\right)$ for 10 days. The seeds were isolated by breaking the pyrenes in a lathe.

The experiment was conducted from August 2010 to September 2011 in a greenhouse with a transparent-fiber roof (at the beginning, $70 \%$ and after $50 \%$ of light interception), ceiling height of $3.5 \mathrm{~m}$, with no walls on the east and north. Inside the greenhouse, during the 426 days of the experiment, mean weekly temperatures ranged from $9.5^{\circ} \mathrm{C}$ at the end of June to $28.7^{\circ} \mathrm{C}$ at the end of January. Absolute temperatures ranged from $3{ }^{\circ} \mathrm{C}$ in early July to $42{ }^{\circ} \mathrm{C}$ in early January.

Initial seedling development. The seedlings were obtained from sowing in a tray with a substrate composed of medium sand and crushed coconut fiber $(1: 2, \mathrm{v} / \mathrm{v})$ and kept in a greenhouse with $70 \%$ light interception for 50 days. Subsequently, the seedlings were transferred to individual packages of black polyethylene with $1.15 \mathrm{~L}$ of substrate composed by carbonized rice husk (CRH) and pine bark (PB) in the ratio of $1: 1(\mathrm{v} / \mathrm{v})$ plus $3 \mathrm{~g} \mathrm{~L}^{-1}$ of Osmocote ${ }^{\circledR}$, a slow-release fertilizer (NPK 19-6-10, no micronutrients). An aliquot of each substrate composition was analyzed in the Laboratory of Substrates of the Faculty of Agronomy of UFRGS, to obtain physicochemical characteristics (table 1).

After 90 days, the plants were transferred to a greenhouse with better illumination (50\% light interception). Every 15 days, the seedlings received top dressing fertilization with a nutrient solution of $2 \mathrm{~g} \mathrm{~L}^{-1}$ (formula - $\mathrm{N}$ : 10.5 , $\mathrm{P}_{2} \mathrm{O}_{5}: 6, \mathrm{~K}_{2} \mathrm{O}: 10.7$, S: 4.6, Ca: 3.8 and $\mathrm{Mg}: 3.2$; Ca:Mg ratio of 1.2 and $\mathrm{NH}_{4}: \mathrm{NO}_{3}$ ratio of 2.6) in $100 \mathrm{~mL}$ of solution for each plant. After 160 days, the plants were removed from the substrate and evaluated for height $(\mathrm{cm})$, stem diameter $(\mathrm{cm})$ and number of leaves.

Fertilizer application in seedlings. After the measurement, the seedlings were established in polyethylene packages with capacity of $8 \mathrm{~L}(23 \times 22 \mathrm{~cm}$ : height, diameter) containing PB substrate sieved in a $10-\mathrm{mm}$ mesh. The treatments consisted of: 1 - control (without fertilization), 2 - fertilization with $0.6 \mathrm{~g} \mathrm{~L}^{-1}$ of salts, 3 - fertilization with $1.2 \mathrm{~g} \mathrm{~L}^{-1}$ of salts, 4 - fertilization with $2.4 \mathrm{~g} \mathrm{~L}^{-1}$ of salts and 5 - fertilization with $3.6 \mathrm{~g} \mathrm{~L}^{-1}$ of salts. The first fertilization was applied at 25 days after installing the experiment and, subsequently, every 30 days in months with average temperature above $18{ }^{\circ} \mathrm{C}$. In the period when temperature was $18{ }^{\circ} \mathrm{C}$ or less, the frequency of application decreased from 30 to 60 days (Broschat 2000). For all treatments, the relation of elements of the fertilization was $\mathrm{N}: 3, \mathrm{P}_{2} \mathrm{O}_{5}: 1, \mathrm{~K}_{2} \mathrm{O}: 2$, S: 2.7, Ca: 2, Mg: 1, $\mathrm{NH}_{4}: \mathrm{NO}_{3}$ (ratio 1:1). The fertilizer formulation was constituted with the salts: potassium chloride, calcium nitrate, magnesium sulfate, monoammonium phosphate, ammonium sulfate and urea.

The need for irrigation was verified through tensiometers (ceramic porous capsule connected to a graduated analog vacuum-gauge) inserted into the substrate at about 15 $\mathrm{cm}$, one per treatment. The plants were manually irrigated with 150 to $200 \mathrm{~mL}$ of water per plant, applied when the negative pressure reached an average of $100 \mathrm{hPa}$ in the tensiometers. The space between vases was $10 \mathrm{~cm}(32 \mathrm{~cm}$ between plants) and after five months, it increased to $25 \mathrm{~cm}$, 
Table 1. Analysis of the physicochemical properties of the substrates.

Análisis de las propiedades fisicoquímicas de los sustratos.

\begin{tabular}{lcc}
\hline \multicolumn{1}{c}{ Determination } & Carbonized rice husk + pine bark $(1: 1, \mathrm{v} / \mathrm{v})$ & Pine bark \\
\hline Humid density $\left(\mathrm{kg} \mathrm{m}^{-3}\right)$ & 487 & 722 \\
Dry density $\left(\mathrm{kg} \mathrm{m}^{-3}\right)$ & 222 & 307 \\
Dry matter $\left(\mathrm{g} 100^{-1}\right)$ & 46 & 42 \\
$\mathrm{pH}\left(\mathrm{H}_{2} \mathrm{O}\right), 1: 5(\mathrm{v} / \mathrm{v})$ water extract & 6.69 & 6.21 \\
Electrical conductivity $\left(\mathrm{mS} \mathrm{cm}^{-1}\right), 1: 5(\mathrm{v} / \mathrm{v})$ water extract & 0.89 & 0.11 \\
Total pore space $\left(\mathrm{m}^{3} \mathrm{~m}^{-3}\right)$ & 0.84 & 0.85 \\
Air space $\left(\mathrm{m}^{3} \mathrm{~m}^{-3}\right)$ & 0.47 & 0.32 \\
Easily available water $\left(\mathrm{m}^{3} \mathrm{~m}^{-3}\right)$ & 0.10 & 0.08 \\
Buffering capacity water $\left(\mathrm{m}^{3} \mathrm{~m}^{-3}\right)$ & 0.02 & 0.02 \\
Available water $\left(\mathrm{m}^{3} \mathrm{~m}^{-3}\right)$ & 0.12 & 0.11 \\
\hline
\end{tabular}

arranged on bricks about $20 \mathrm{~cm}$ from the ground, which was covered with $25 \mathrm{~cm}$ of coarse gravel.

Assessments. During the experiment, the electrical conductivity and $\mathrm{pH}$ of the substrate were evaluated every 30 days using the PourThru method (Cavins et al. 2000). After the sixth evaluation, monitoring occurred in the periods of 1 , 10,20 and 30 days after the fertilizer application, using two containers randomly chosen for each treatment. The measurements of the plants, such as stem diameter $(\mathrm{cm})$, the total number of leaves and number of pinnate leaves were analyzed every 30 days.

Along with the development of seedlings, the symptoms of nutritional disorders and the occurrence of pests were monitored, and in the latter case, collected and identified when observed on the plants. Nutritional disorders were assessed using an increasing visual scale ranging from one to three, depending on the intensity of the symptoms on the leaves. Number one was assigned to plants with no symptoms or mild symptoms, in other words, the youngest leaf with initial chlorosis; two for plants with a higher number of young chlorotic leaves and three for plants with young leaves totally yellow and, in some cases, necrotic edges.

The pests or part of the attacked plant were collected and sent to the Department of Plant Health of the Faculty of Agronomy of UFRGS and State Agricultural Research Foundation for analysis. For pest mitigation in the spring/ summer, mineral oil (1.5\%) and Bacillus thuringiensis $\left(\right.$ Dipe $\left.^{\mathbb{R}}\right)\left(3 \mathrm{~g} \mathrm{~L}^{-1}\right)$ were applied every 30 days, and in January, two doses of acephate at $1 \mathrm{~g} \mathrm{~L}^{-1}$ (Orthene ${ }^{\circledR} 750 \mathrm{BR}$ ).

Statistical analyses. The experimental design was in random blocks, in which the blocking factor was the origin of the seedlings. Each plot consisted of ten plants: the block 1 corresponded to plants from seeds of Santa Vitória do Palmar and the block 2 of seeds collected in Encruzilhada do Sul, totaling 100 plants. Variables underwent the normality test of Kolmogorov-Smirnov and homoscedasticity test of Levene, and when one of these two requirements were not fulfilled, the data were transformed according to the variable and subsequently submitted to normality and homoscedasticity tests again.

\section{RESULTS}

According to table 1, the physicochemical analysis of the pine bark substrate showed similar values to those referred to as ideal in literature. Electrical conductivity, throughout all the period, presented a very distinct range among treatments. However, in the evaluations of the period corresponding to the 6th and 7th fertilization (218 and 242 days), there was little variation. The regression analysis did not indicate a significant trend for these two variables related to the fertilizer doses applied. The electrical conductivity of the control treatment ranged from 0.2 to $0.25 \mathrm{mS} \mathrm{cm}^{-1}$, while the others had distribution compatible with the fertilizer dose concentration, on average $2.45 \mathrm{mS} \mathrm{cm}^{-1}$ for the dose with $0.6 \mathrm{~g} \mathrm{~L}^{-1}, 5.6 \mathrm{mS}$ $\mathrm{cm}^{-1}$ for $1.2 \mathrm{~g} \mathrm{~L}^{-1}, 9.3 \mathrm{mS} \mathrm{cm}^{-1}$ for $2.4 \mathrm{~g} \mathrm{~L}^{-1}$ and $12.4 \mathrm{mS}$ $\mathrm{cm}^{-1}$ for $3.6 \mathrm{~g} \mathrm{~L}^{-1}$, respectively. Therefore, the electrical conductivity of the substrate remained constant, even at the lowest concentrations.

A similar variation was observed for $\mathrm{pH}$, which was also different in relation to fertilizer concentrations. In the control treatment, $\mathrm{pH}$ ranged between 6.2 and 6.4, which corresponds to an index close to the value found at the beginning of the experiment. The higher the concentration of the fertilizer dose, the more acid became the substrate. 
There was a gradual electrical conductivity increase in the substrate of all treatments since the beginning of fertilizer applications, except for the control treatment. From 218 days after the start of the experiment (after sixth fertilization), there was a decrease in electrical conductivity of substrate treatments corresponding to 2.4 and $3.6 \mathrm{~g} \mathrm{~L}^{-1}$ while in the others, maximum electrical conductivity was after 316 days.

The $\mathrm{pH}$ of the treatments with lower dosages $(0.6 \mathrm{e}$ $1.2 \mathrm{~g} \mathrm{~L}^{-1}$ ), besides control treatment, ranged from 5.3 and 6.6 throughout the experiment. There was no significant trend of $\mathrm{pH}$ change due to fertilization in these treatments. However, this effect did not occur in other treatments, since the regression analysis indicated a quadratic trend with variation similar to that observed for electrical conductivity variable, although inversely proportional. In other words, while electrical conductivity increased, $\mathrm{pH}$ decreased (figure 1).

The statistical analysis showed a significant difference in the five concentrations of fertilizers for all variables related to plant development (total number of leaves, steam diameter and number of pinnate leaves). Between blocks, there was a difference only for the stem diameter (table 2). Thus, it is evident that plants responded differently according to fertilizer doses and that the genotypic effect influenced the performance of seedlings in terms of stem diameter, so that the seedlings originated from seeds collected in Santa Vitória do Palmar (block 1) presented a larger diameter when compared to those of Encruzilhada do Sul (block 2).

The regression analysis showed a decreasing linear trend for the number of leaves, indicating that high doses of fertilizer inhibit the emission of leaves (figure 2). Among the averages of treatments, the maximum number

Table 2. Analysis of variance of the final development of Butia odorata seedlings from two accesses submitted to the five concentrations of fertilizers, at 426 days after the installation of the experiment.

Análisis de la varianza del desarrollo final de las plantas de Butia odorata de dos accesiones sometidas a las cinco concentraciones de fertilizantes, a los 426 días después de la instalación del experimento.

\begin{tabular}{lccc}
\hline & $\begin{array}{c}\text { Total } \\
\text { number of } \\
\text { leaves }\end{array}$ & $\begin{array}{c}\text { Stem } \\
\text { diameter } \\
(\mathrm{cm})\end{array}$ & $\begin{array}{c}\text { Number } \\
\text { of pinnate } \\
\text { leaves }\end{array}$ \\
\hline Treatments & $P=0.02$ & $P<0.01$ & $P<0.01$ \\
Blocks & $P=0.37$ & $P<0.01$ & $P=0.09$ \\
Overall average & 12.42 & 5.37 & 7.24 \\
Standard deviation & 1.6 & 0.75 & 1.41 \\
CV $(\%)$ & 12.24 & 11.37 & 17.71 \\
\hline
\end{tabular}

$\mathrm{TNL}=$ número total de hojas; $\mathrm{SD}=$ diámetro del tallo; $\mathrm{NPL}=$ número de hojas pinnadas. of leaves per plant was 13.3, while the minimum was 11 . For the variables stem diameter and number of pinnate leaves, the regression analysis indicated a significant negative quadratic trend with the points of maximum response in

A

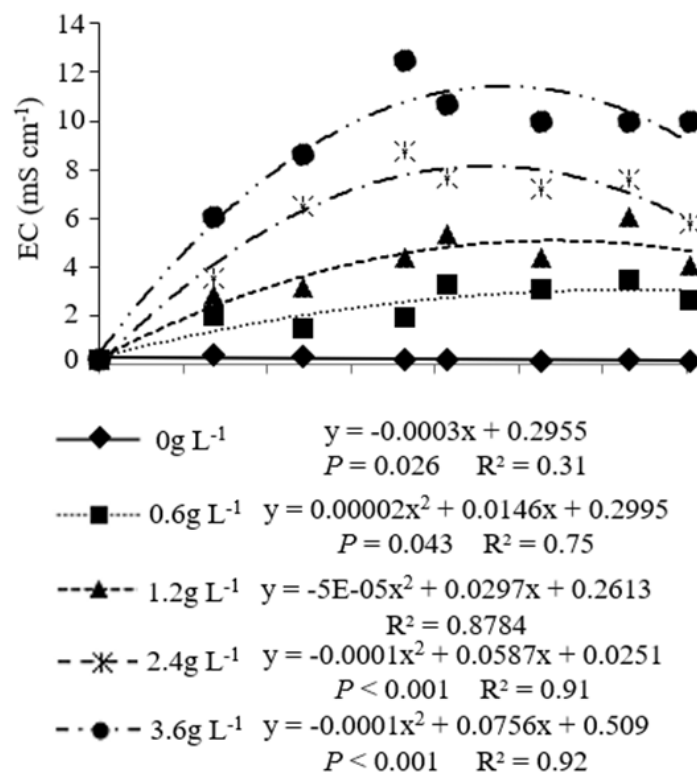

B
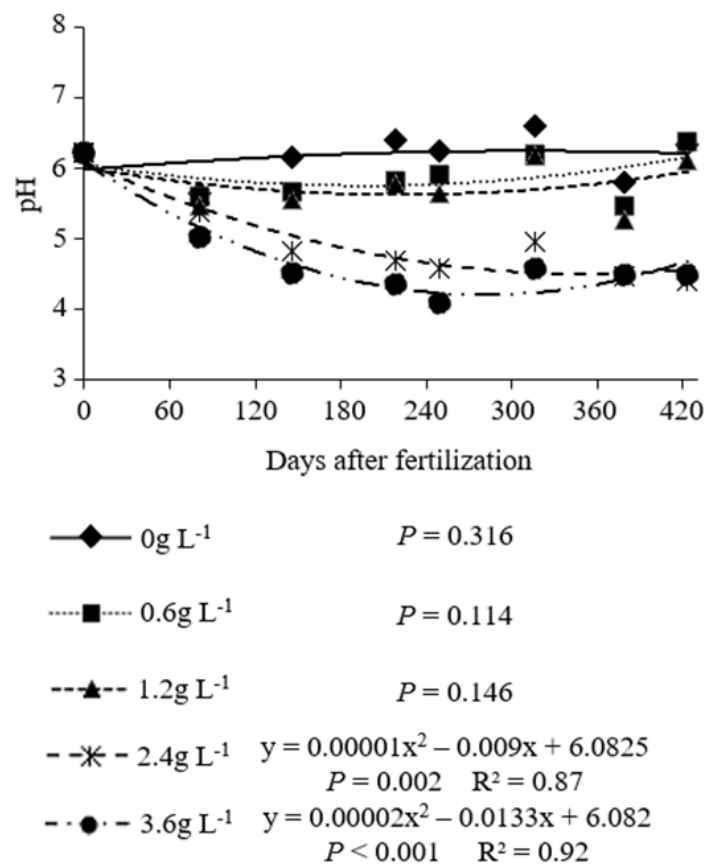

Figure 1. $\mathrm{pH}$ (A) and electric conductivity (EC) (B) of the pine bark (PB) substrate with seedlings of Butia odorata, submitted to five concentrations of fertilizers $\left(0,0.6,1.2,2.4\right.$ and $\left.3.6 \mathrm{~g} \mathrm{~L}^{-1}\right)$ for 426 days in greenhouse.

$\mathrm{pH}$ (A) y conductividad eléctrica (EC) (B) del sustrato de corteza de pino (PB) con plantas de Butia odorata, sometidas a cinco concentraciones de fertilizantes $\left(0,0,6 ; 1,2 ; 2,4\right.$ y $\left.3,6 \mathrm{~g} \mathrm{~L}^{-1}\right)$ durante 426 días en invernadero. 


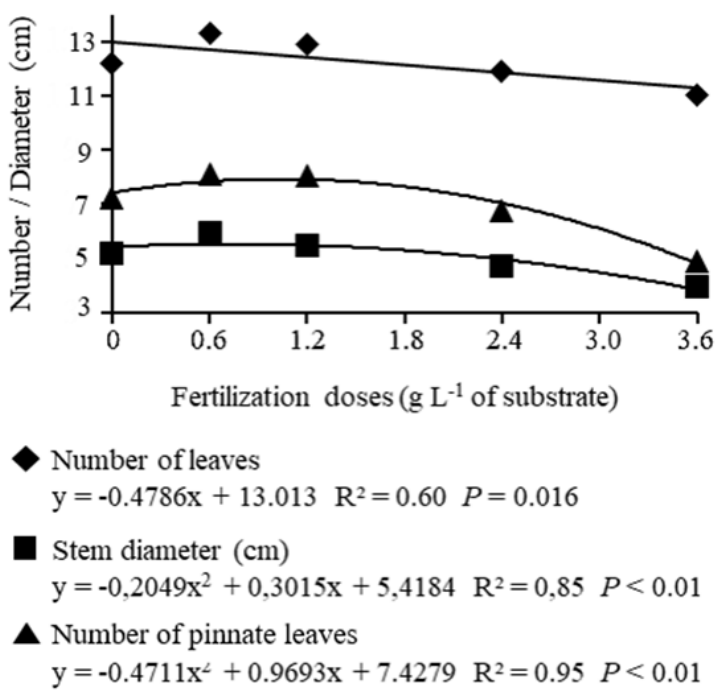

Figure 2. Number of leaves, stem diameter, and number of pinnate leaves in Butia odorata seedlings, submitted to five concentrations of fertilizers $\left(0,0.6,1.2,2.4\right.$ and $\left.3.6 \mathrm{~g} \mathrm{~L}^{-1}\right)$ during 426 days.

Número de hojas, diámetro del tallo y número de hojas pinnadas en plantas de Butia odorata fertilizadas, sometidas a cinco concentraciones de fertilizantes $\left(0 ; 0,6 ; 1,2 ; 2.4\right.$ y $\left.3 ., 6 \mathrm{~g} \mathrm{~L}^{-1}\right)$ durante 426 días.

0.74 and $1.1 \mathrm{~g} \mathrm{~L}^{-1}$ for stem diameter and number of pinnate leaves, respectively (figure 2).

The dosages that induced higher responses in the analyzed variables were 0.6 and $1.2 \mathrm{~g} \mathrm{~L}^{-1}$. Thus, the electric conductivity from the leachate of these treatments gradually increased from the beginning of applications to about 10 months, when it had stabilized and declined, possibly due to the decrease in the frequency of fertilization. However, according to the regression equation, the maximum electric conductivity of these treatments was $5 \mathrm{mS} \mathrm{cm}^{-1}$ in the concentration of $1.2 \mathrm{~g} \mathrm{~L}^{-1}$.

As for the number of photosynthetically active leaves per plant, there was a continuous increase up to about 270 days. From this period, the number of leaves remained relatively stable, with a slight increase from 360 days after the installation of the experiment (figure 3A).

The emission of the first pinnate leaves occurred at 120 days from the beginning of the transplant (about 440 days from the germination). At 148 days, $28 \%$ of the plants emitted at least one pinnate leaf, with no statistical difference among treatments (Kruskal-Wallis, $P=0.662$ ) and at 178, 209 and 242 days, 74, 86 and $97 \%$, respectively. The emission of pinnate leaves in at least $50 \%$ of the plants occurred approximately 480 days (about 16 months), considering that in the installation of the experiment the seedlings had 322 days from germination.

The evolution of the stem diameter in the treatments with the two lower doses of fertilizers was practically continuous, even with reduced temperatures and photoperiod (figure $3 \mathrm{C}$ ). The evolution of this variable was very similar
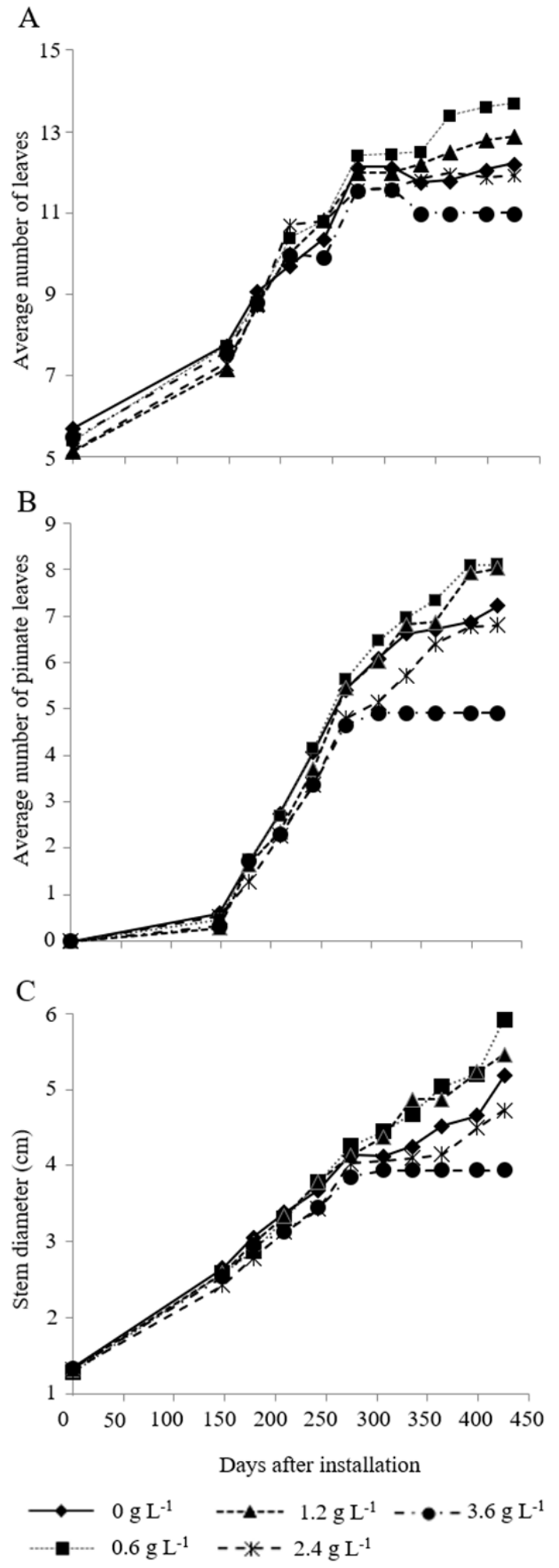

Figure 3. Average number of leaves (A), average number of pinnate leaves (B) and stem diameter (C) in Butia odorata seedlings, submitted to five concentrations of fertilizers $(0,0.6,1.2,2.4$ and $3.6 \mathrm{~g} \mathrm{~L}^{-1}$ ) during 426 days.

Número promedio de hojas (A), número promedio de hojas pinnadas (B) y diámetro del tallo (C) en plantas de Butia odorata, sometidas a cinco concentraciones de fertilizantes $\left(0 ; 0,6 ; 1,2 ; 2,4\right.$ y $\left.3,6 \mathrm{~g} \mathrm{~L}^{-1}\right)$ durante 426 días. 
in the second stage of the experiment with the initial development of seedlings.

Nutritional disorders and occurrence of pests. Symptoms observed as a result of nutritional disorders have been monitored since leaf emission, nonetheless they were found only from the evaluation 242 days after the beginning of fertilization, through the visualization of young chlorotic leaves. In this evaluation, $100 \%$ plants fertilized with 3.6 $\mathrm{g} \mathrm{L}^{-1}$ showed symptoms, while in the treatment with the second highest dose $\left(2.4 \mathrm{~g} \mathrm{~L}^{-1}\right)$, the percentage was $85 \%$. In the latter case, the percentage of plants with symptoms varied according to the period, with a reduction in the intensity of symptoms, which coincided with the months of lower temperature and photoperiods. The increase in symptom intensity was restarted from the end of winter, reaching $100 \%$ of plants in early spring.

In the other treatments, the maximum percentage of plants with symptoms occurred among unfertilized plants (control), reaching $40 \%$, also in late spring. The lowest percentage of symptomatic plants was observed in the treatment with the dosage of $0.6 \mathrm{~g} \mathrm{~L}^{-1}$, which varied from 0 to $10 \%$, during the entire period of the experiment.
In most cases, the evolution of symptoms occurred from the tissues of the younger leaves to the older leaves, both during treatments and during the evaluation period in the same treatment. A slight partial bleaching was observed in the younger leaf, which could evolve to the other areas, while other leaves presented large portions or the entire leaf area with pale yellow pigmentation. In severe cases, the leaves are uniformly yellow, while some have necrotic edges (figure 4). In some plants, depending on the fertilizer concentration, the symptoms started in the older leaves.

In the control treatment and in the two lowest doses ( 0.6 and $\left.1.2 \mathrm{~g} \mathrm{~L}^{-1}\right)$, the intensity of symptoms was low. The mean score of symptoms between treatments was "1", evidenced by the higher percentage of plants with better visual appearance when submitted to fertilization (figure 4A) compared to the control (figure 4B). In the second highest dose $\left(2.4 \mathrm{~g} \mathrm{~L}^{-1}\right)$, most plants received a score of " 2 " on the intensity scale (figure 4C, D).

The intensity of the symptoms was higher in the treatment with higher doses of fertilizer $\left(3.6 \mathrm{~g} \mathrm{~L}^{-1}\right.$ of salts), in which $100 \%$ of the plants reached the maximum scale (number 3 ) about 330 days after the beginning

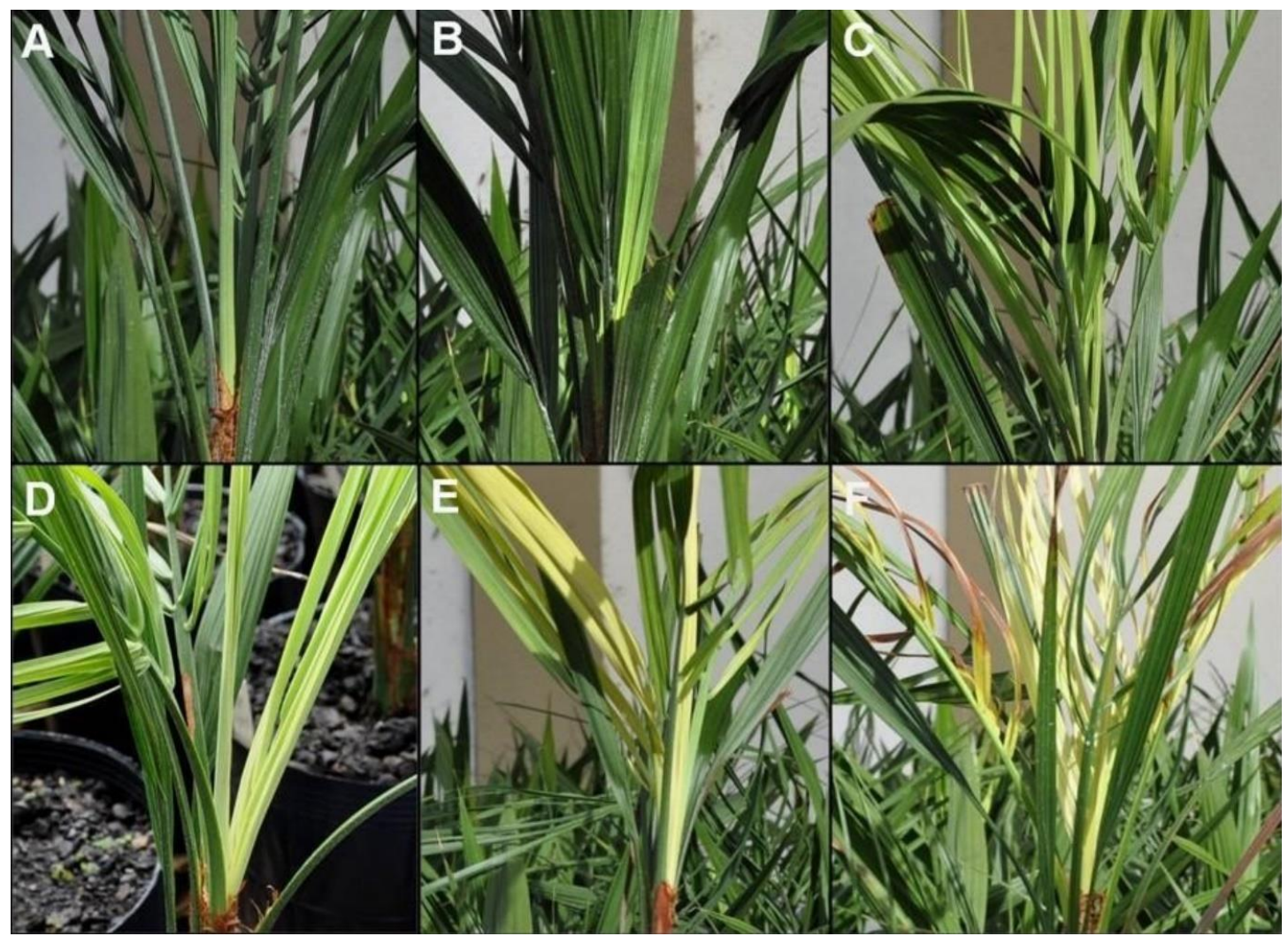

Figure 4. Evolution of the intensity of the symptoms of nutritional disorder in Butia odorata seedlings. A-B: scale 1 (absence of symptoms at mild intensity), C-D: scale 2 (medium intensity), E-F: scale 3 (high intensity).

Evolución de la intensidad de los síntomas del trastorno nutricional en plantas de Butia odorata. A-B: escala 1 (ausencia de síntomas a intensidad leve); C-D: escala 2 (intensidad media); E-F: escala 3 (alta intensidad). 
of fertilization. In this condition, in addition to a higher number of young leaves uniformly yellowed, leaves with necrotic edges were observed, although the older leaves remained dark green and without symptoms of nutritional disorders (figure 4E, F). Still, three plants of this treatment died, showing the species intolerance to this level of salinity.

The pest attack started in the spring when the appearance of scale insects of the species Abgrallaspis cyanophylli (Signoret, 1869) (figure 5A) and black aphis (Aphididae) were observed, regardless of the fertilizer treatment. In the same period, caterpillars were found feeding on pri- mary leaves and, for their control, the application of Bacillus thuringiensis Berliner was efficient (figure 5B).

Eventually, symptoms and signs of thrips (Thysanoptera, Phalaeothripidae) were observed, which is characterized by semicircular whitish points in the limbus of primary leaves.

During the summer, mites (Eriophyidae) (figure 6A and B) caused symptoms in newly emitted leaves, similar to foliar stains caused by nutritional disorders (figure 6C). The mites attacked the bases of new leaves, mainly in the region near the point of growth.

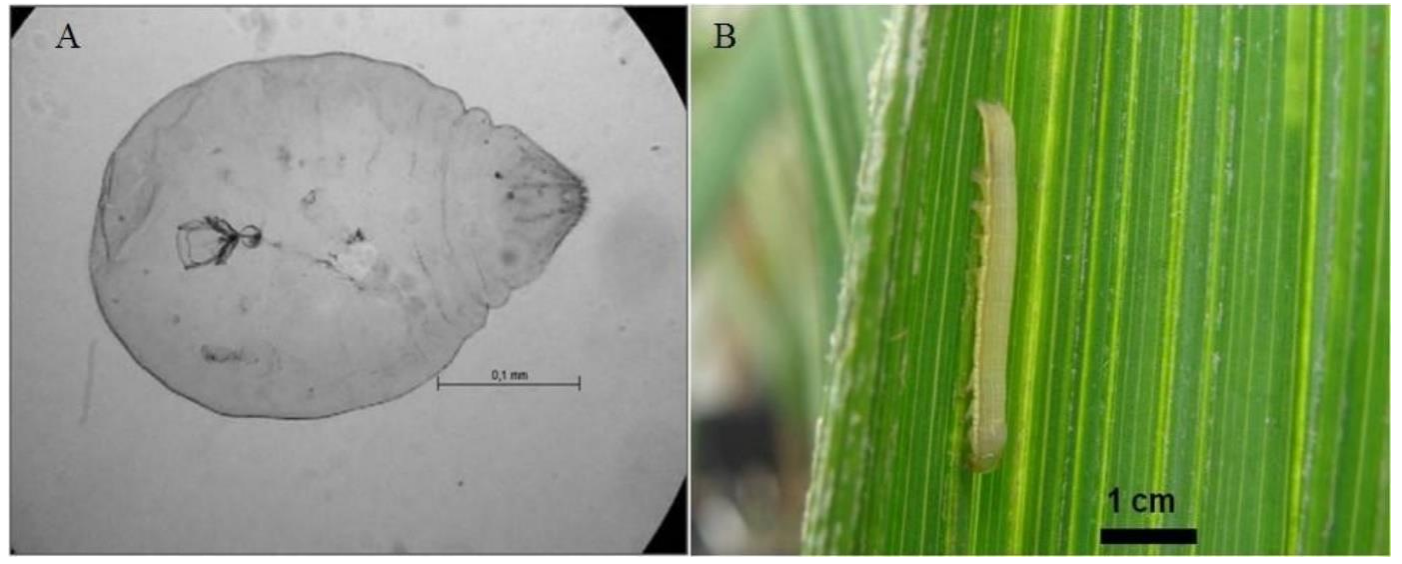

Figure 5. "Scale insect Abgrallaspis cyanophylli (A) and caterpillars on primary leaves (B) of Butia odorata seedlings. *Collection and processing: Gabriela Chesim de Souza; Identification: Dr. Vera Wolff.

*Escala de insectos Abgrallaspis cyanophylli (A) y orugas en las hojas primarias (B) de las plantas de Butia odorata. *Recolección y procesamiento: Gabriela Chesim de Souza; Identificación: Dra. Vera Wolff.

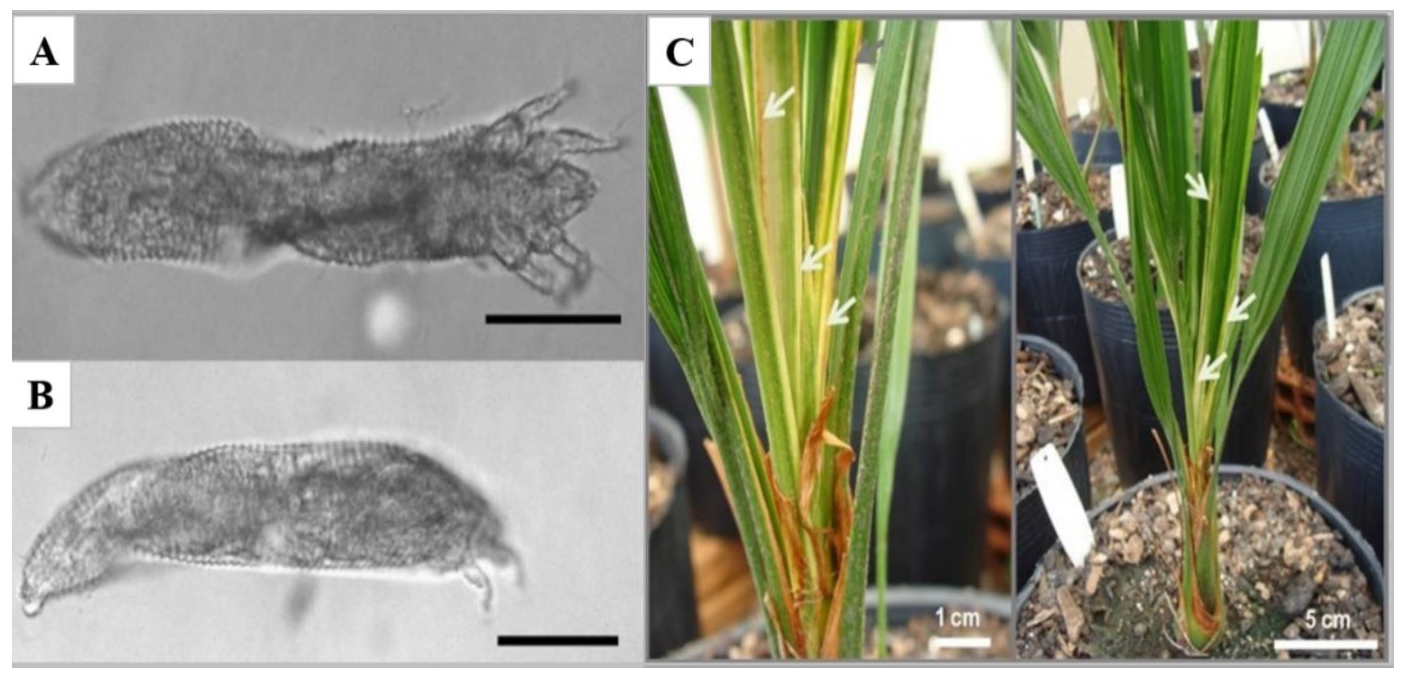

Figure 6. Illustration of the mite (Eriophyidae). A: ventral view, B: side view. Scales bars: $50 \mu \mathrm{m}$. Symptom of attack of Eriophyidae in Butia odorata seedlings (C). Identification and image: Dr. Ana Paula Ott.

Ilustración del ácaro (Eriophyidae). A: vista ventral e B: vista lateral. Barras de escalas: $50 \mu \mathrm{m}$. Síntoma de ataque de Eriophyidae en plantas de Butia odorata (C). Identificación e imagen: Dra. Ana Paula Ott. 


\section{DISCUSSION}

In this study, the seedlings of $B$. odorata were conditioned in a place with climate and photoperiod conditions similar to those of natural occurrence of the species. Regarding fertilization, no studies with the species were found. In addition, the works available with fertilization of other species of the genus Butia are scarce. However, there are reports of positive effects of fertilizer additions on the formation of seedlings in species of other genera of the Arecaceae family. Teixeira et al. (2009) evaluated the growth of seedlings from pre-emerged seeds of the palm Elaeis guineensis Jacq. on a commercial substrate without fertilization and with addition of $3 \mathrm{~kg} \mathrm{~m}^{3}$ of two different slow-release fertilizers for three months. According to these authors, the addition of fertilizers to the substrate was a determining factor in this phase, interfering significantly in all analyzed variables and fundamental for the final formation of seedlings.

As for the substrate, the dry density is within the appropriate ranges (300 a $500 \mathrm{~kg} \mathrm{~m}^{3}$, Kämpf 2005), as well the air space $(20-30 \%)$ and the total pore space $(85 \%)$ (De Boodt and Verdonck 1972). However, the range of available water is out of the referred as ideal for most species, which is $30 \%$ (De Boodt and Verdonck 1972). Therefore, tensiometers were used to intensify the monitoring of the water availability in the substrate, to avoid water deficiency in the plants. Initially, as indicated by tensiometers, the irrigation periodicity was weekly or every five days. Subsequently, the irrigations were more constant (every two days), and at the end of the experiment, they were daily.

The variation in electric conductivity and substrate $\mathrm{pH}$ occurred during the sixth and seventh fertilizer application (February), and can be explained as a consequence of the increased irrigation frequency due to the higher evaporative demand in this period, mainly due to high temperature, which may have contributed to the leaching of part of the salts.

The time difference for the electric conductivity change, associated with the quadratic tendency of the regression of all treatments, suggests that while applications were every 30 days, accumulation and saturation were gradual, which occurred earlier in the higher dosage treatments. With fertilization applied in a larger range, there was partial leaching and consequent drop in electric conductivity.

The decrease in electric conductivity observed in the higher dose treatments (2.4 and $\left.3.6 \mathrm{~g} \mathrm{~L}^{-1}\right)$ occurred after the sixth fertilization and can be explained by the reduction in the frequency of applications since the interval increased from 30 to 60 days. This fact was also observed in other treatments after the increase in the application interval, in other words, decreasing its frequency.

The $\mathrm{pH}$ variation of the lower dosage treatments (0.6 and $\left.1.2 \mathrm{~g} \mathrm{~L}^{-1}\right)$ was very similar, suggesting a substrate buffering effect for these fertilizer doses. Except for treatments with the highest dosages (2.4 and $\left.3.6 \mathrm{~g} \mathrm{~L}^{-1}\right)$, the $\mathrm{pH}$ remained in a range considered suitable for most substrate crops. According to Handreck and Black (2010), in general, the $\mathrm{pH}$ of the substrate for crops needs to be between 5.5 and 6.3 for palm trees grown in containers. For the availability of all nutrients, Bataglia and Furlani (2010) recommend $\mathrm{pH}$ between 5 and 6.

According to plant development results, it can be inferred that $5 \mathrm{mS} \mathrm{cm}^{-1}$ is the maximum electric conductivity tolerated by the species, once under higher salinity levels, a decreased growth intensity may occur. The higher responses in the analyzed variables indicate that the tolerance to salinity in the substrate aiming at superior seedling development, $B$. odorata is within the electric conductivity range considered adequate for most species. According to Cavins et al. (2000), this range is between 2.6 and $4.5 \mathrm{mS}$ $\mathrm{cm}^{-1}$, determined by the PourThru method. According to the same authors, the electric conductivity above $4.6 \mathrm{mS}$ $\mathrm{cm}^{-1}$ is high and decreases the vigor and growth rate of most species.

As reported by Kämpf (2000), regarding salt sensitivity, plants are divided among very sensitive, whose fertilization cannot exceed $1 \mathrm{~g}$ of salts per liter of substrate; tolerant plants, whose acceptable range is 1 to $2 \mathrm{~g} \mathrm{~L}^{-1}$; and demanding plants, whose fertilization is about $3 \mathrm{~g} \mathrm{~L}^{-1}$. Based on this classification, the results of this study reveal that $B$. odorata is between the sensitive and tolerant plants since the best response range for the stem diameter and the number of pinnate leaves was 0.74 and $1.1 \mathrm{~g} \mathrm{~L}^{-1}$, respectively.

Geymonat and Rocha (2009) describe B. odorata as a species tolerant to salinity and resistant to coastal environment conditions, used for ornamental purposes in this type of environment in several parts of the world. Richards (1954) reported that saline soils analyzed by the "saturated pulp" method presented electric conductivity above 4 mmho $\mathrm{cm}^{-1}\left(1 \mathrm{mmho} . \mathrm{cm}^{-1}=1 \mathrm{mS} \mathrm{cm}^{-1}\right)$, corresponding to $5.22 \mathrm{mS} \mathrm{cm}^{-1}$ when determined by the PourThru method (Cavins et al. 2000). Therefore, the soil may be considered saline when electric conductivity is higher than $5.22 \mathrm{mS} \mathrm{cm}^{-1}$ determined by the PourThru method, which is above the maximum limit that the $B$. odorata seedlings supported without interference in the development. Thus, to cultivate the species aiming at the maximum development, saline conditions should be avoided at least until the juvenile stage.

The emission of the first pinnate leaves occurred one year and three months after seed germination under the conditions of seedling production, in a greenhouse without automatic control of temperature and humidity, with $50 \%$ shading and with irrigation management and fertilizers. The stabilization of the total number of leaves per plant after 270 days probably occurred due to the beginning of the emission of pinnate leaves, which are larger and, consequently, may require more energy from the plant for its formation. Besides, environmental conditions were unfavorable for photosynthesis during this period. 
For seedlings of Syagrus romanzoffiana (Cham.) Glassman., a palm tree species, 480 days were required for $50 \%$ of the plants to emit pinnate leaves in the greenhouse, which can be considered the time to reach the "Juvenile 2 " phase (Bernacci et al. 2008). However, for B. odorata, it was not possible to clearly distinguish the "Juvenile 1 " phase, which, according to these authors, is characterized by the presence of thicker young eophiles before the emission of pinnate leaves (figure 3B). The average increase in the number of pinnate leaves per plant was practically continuous and uniform from the beginning of the emission until the middle of March. From this period, it was less intense, possibly due to the decrease in temperature and photoperiods.

The behavior of stem diameter evolution observed in the treatments with the lowest dosages seems to be a characteristic of the species, whose leaf emission intensity decreases when environmental conditions are less favorable, although the development in stem thickness remains. This is an interesting information to investigate because it seems that during the favorable period for photosynthesis, photoassimilates are destined to several demands of the vegetal development, while in the short period of low temperatures, the priority development is the increase in stem thickness.

Nutritional disorders and occurrence of pests. The maximum percentage of plants with symptoms among the unfertilized plants can be explained by insufficient nutrients provided by the substrate, triggering the onset of symptoms in late spring. On the other hand, in fertilized plants, the appearance of symptoms suggests that the range of 4 to $5 \mathrm{mS} \mathrm{cm}^{-1}$ represents the electric conductivity limit tolerated by the species without decreasing the growth rate, confirming the results on plant development.

The average symptom scale " 2 " observed at the second highest dose indicates that this level of salinity, although high, does not cause serious damage to plants. As reported on the percentage of plants with symptoms, reduction in intensity was also observed during the winter, the period in which, besides the difference in climatic variables and decrease in evaporative demand, there was a reduction in the frequency of application of fertilizer doses.

According to Bataglia and Furlani (2010), the symptoms of nutritional disturbance observed in young leaves of palm trees may be associated with deficiency of calcium, sulfur, boron, iron, manganese, zinc and copper. Thus, for these authors, changes in palm development due to nutritional disorders may also be associated with excess nutrients. This information corroborates the data of the present work. Broschat (2009) reports that the leaching and insolubility of nutrients in containers are not very problematic, due to the retention resulting from the acidic $\mathrm{pH}$ of substrates. However, organic substrates limit nitrogen levels, which is considered by this author the most important nutritional problem in the production of palm trees in containers. However, in this case, the symptoms occur in older leaves, reaching younger ones progressively.

For Bataglia and Furlani (2010), the uniformly yellowish coloration of young palm leaves is a symptom of sulfur deficiency. Considering that the symptoms observed in the plants of this study closely resemble this description, it can be inferred that despite the application of sulfur as part of the fertilization, possibly the excess of salinity, promoted the absorption in superior proportion of some elements to the detriment of others. This can explain the presence of the symptoms of sulfur deficiency.

Visual diagnosis is the simplest procedure for identifying nutritional problems and is suitable for nitrogen, potassium, magnesium, manganese and boron. Many deficiencies, however, have similar symptoms, which leads to the need for chemical analyses for confirmation (Bataglia and Furlani 2010). Chemical analyses of plant tissues were not performed in this study since the removal of parts of the plants for analyses could compromise the execution of subsequent experiments. These experiments are mainly related to investigations of the juvenile period of plants established in the field and will continue to be accompanied as part of a project, after the present work. However, it should be noted that evaluation by tissue analyses is imperative for an upcoming study, to confirm whether the observed symptoms confer with literature information for other palm species.

The symptoms of nutritional disturbance observed in the leaves of the plants of some treatments probably occurred because of the excess salinity in the substrate, making absorption difficult, due to the reduction of water potential. The dissolved solutes in the zone of the roots of plants generate a low osmotic potential (more negative) which decreases soil water potential. Thus, general water balance is affected, because, to develop, plants need even lower potential to maintain a gradient of water potential between the soils and leaves (Taiz et al. 2017).

Plants under stress due to lack of water or excessive salinity are stimulated to accumulate and maintain high levels of organic solutes in the cytoplasm at the expense of energy diverted from growth functions. Moreover, these authors affirm that the accumulation of osmoregulators is a way to reduce the internal osmotic potential of cells, and consequently, water potential, generating a gradient favorable to the absorption by the roots (Taiz et al. 2017). This phenomenon is called osmotic adjustment or osmotic conditioning and reduces the growth rate of plants (Carillo et al. 2011). This information may justify the reduction of rate development of the seedlings of treatments with the highest fertilizer dosages.

Even in the most favorable treatments $\left(0.6\right.$ e $\left.1.2 \mathrm{~g} \mathrm{~L}^{-1}\right)$, the development of seedlings was not uniform in relation to the three variables. It seems that a definition of priority in the development of vegetative structures is determined, in part, by the availability of photoassimilates. Thus, it is likely that stem thickening occurred continuously, regard- 
less of the time of the year. The emission of leaves during the juvenile phase seems to follow a synchronism oriented by the relation leaves/pinnate leaves. When the formation of pinnate leaves began, the intensity of the increase in the total number of leaves decreased, and for the two apparently less favorable treatments (control and higher dosage), there was a decrease in the total number of photosynthetically active leaves in the winter. This suggests that the plant sacrifices some primary leaves to supply the emission of pinnate leaves when conditions are less favorable for the production of photoassimilates. However, it is only a speculation since the analysis does not allow detailed physiological conclusions.

Regarding the occurrence of pests, for control of scale insects, doses of mineral oil were applied, which also decreased the incidence of aphis. In the case of thrips symptoms and signs, specific phytosanitary products were not used to control these insects.

For mite control, $1 \mathrm{~g} \mathrm{~L}^{-1}$ of acephate (Orthene ${ }^{\circledR} 750$ BR) was applied at an interval of 15 days. From the second application, recent symptoms have not been noticed in plants. It is unlikely that the infestation of mites would have caused the death of seedlings in the development phase. However, in germination studies conducted at the same time, losses of newly germinated seedlings with the same symptoms described previously have occurred, followed by an aspect of drought in the aerial part of the whole plant. Possibly, mites caused these damages at the point of growth of plants.

\section{CONCLUSIONS}

Butia odorata responds positively to fertilization during seedling formation at doses of 0.6 and $1.2 \mathrm{~g} \mathrm{~L}^{-1}$. However, until the juvenile stage, its development is held back if fertilization elevates the electrical conductivity of the substrate solution to levels higher than $5 \mathrm{mS} \mathrm{cm}^{-1}$.

\section{ACKNOWLEDGMENTS}

The authors thank Capes (Coordenação de Aperfeiçoamento de Pessoal de Nível Superior), CNPq (Conselho Nacional de Desenvolvimento Científico e Tecnológico) and FAPERGS (Fundação de Amparo à Pesquisa do Estado do Rio Grande do Sul) for financial assistance and for the accomplishment of the research.

\section{REFERENCES}

Barbieri RL, JCC Gomes, A Alercia, S Padulosi. 2014. Agricultural Biodiversity in Southern Brazil: Integrating Efforts for Conservation and Use of Neglected and Underutilized Species. Sustainability 6(2): 741-757. DOI: https://doi. org/10.3390/su6020741.

Barbieri RL, MM Marchi, GC Gomes, CH Barros, CM Mistura, JEF Dornelles, G Heiden, GT Beskow, RA Ramos, JCB Villela, FA Dutra, FA Costa, EES Júnior, LA Sampaio, P Lan- zetta, PSG Rocha, N Rocha, M Pippo, J Debeizes, M Rivas. 2015. Vida no butiazal. Brasília, Brazil. Embrapa. 200 p.

Bataglia OC, Furlani PR. 2010. Adubação. In Mathes LAF, RP Uzzo eds. Palmeiras Ornamentais: produção e cultivo. Campinas, Brazil. Fundag. p. 43-57.

Bernacci LC, FR Martins, FAM dos Santos. 2008. Estrutura de estádios ontogenéticos em população nativa da palmeira Syagrus romanzoffiana (Cham.) Glassman (Arecaceae). Acta Botanica Brasilica 22(1): 119-130. DOI: https://doi. org/10.1590/S0102-33062008000100014.

Broschat TK. 2000. Palm nutrition guide. Circular SS-ORH-02. Gainesville, Florida, United States. University of Florida Extension. 6 p.

Broschat TK. 2009. Palm Nutrition and Fertilization. Hort Technology 19(4): 690-694. DOI: https://doi.org/10.21273/ HORTSCI.19.4.690.

Büttow MV; RL Barbieri, RS Neitzke, G Heiden. 2009. Conhecimento tradicional associado ao uso de butiás (Butia spp., Arecaceae) no sul do Brasil. Revista Brasileira de Fruticultura 31(4): 1069-1075. DOI: https://doi.org/10.1590/ S0100-29452009000400021.

Carillo P, MG Annunziata, G Pontecorvo, A Fuggi, P Woodrow. 2011. Salinity stress and salt tolerance. In Shanker A, B Venkateswaralu eds. Abiotic Stress in Plants- Mechanisms and Adaptations. Rijeka, Croatia. InTech Publisher. 428 p.

Cavins TJ, JL Gibson, BE Whipker, WC Fonteno. 2000. pH and EC Meters - Tool for Substrate Analysis. Raleigh, USA. NC State University. Floriculture Research Report FLOREX.001.

Deble LP, JNC Marchiori, FS Alves, AS Oliveira-Deble. 2011. Survey on Butia (Becc.) Becc. (Arecaceae) from Rio Grande do Sul State (Brazil). Balduinia 30: 03-24. DOI: https:// doi.org/10.5902/2358198013883.

De Boodt M, O Verdonck. 1972. The physical properties of the substrates in horticulture. Acta Horticulturae 26: 37-44. DOI: https://doi.org/10.17660/ActaHortic.1972.26.5

Geymonat G, N Rocha. 2009. M’botiá. Ecosistema único en el mundo. Montevideo, Uruguay. Casa Ambiental Castillos. $405 \mathrm{p}$.

Handreck K, N Black. 2010. Growing media for ornamental plants and turf. $4^{\text {th }}$ ed. Sydney, Australia. University of New South Wales. $551 \mathrm{p}$

Kämpf AN. 2005. Produção comercial de plantas ornamentais. $2^{\text {nd }}$ ed. Guaíba, Brazil. Agrolivros. 256 p.

Kämpf AN. 2010. Seleção de materiais para uso como substratos. In Kämpf AN, MH Fermino eds. Substratos para plantas: a base da produção vegetal em recipientes. Porto Alegre: Gênesis. p. 139-145.

Lorenzi H, L Noblick, F Kahn, E Ferreira. 2010. Flora brasileira: Arecaceae (Palmeiras). Nova Odessa, Brazil. Instituto Plantarum. 367 p.

Marcato AC. 2004. Revisão taxonômica do gênero Butia (Becc.) Becc. (Palmae) e filogenia da sub-tribo Buttiinae Sakov (Palmae). Tese de Doutorado. São Paulo, Brasil. Universidade de São Paulo. 147 p.

Marchi MM, RL Barbieri, JM Sallés, FA da Costa. 2018. Flora herbácea e subarbustiva associada a um ecossistema de butiazal no Bioma Pampa. Rodriguésia 69(2): 553-560. DOI: https://doi.org/10.1590/2175-7860201869221.

Paim LP, MP Paim. 2016. Uso de mudas de Butia lallemantii (Deble et Marchiori) para recuperar áreas degradadas por arenização no município de Alegrete-RS. Revista Congrega 


\section{3: 984-994.}

Richards LA. 1954. Diagnosis and improvement of saline and alkali soils. Washington, USA. USSL. 160 p. (USDA. Agriculture Handbook 60)

Rio Grande do Sul. 2014. Lista da flora gaúcha ameaçada de extinção. Accessed Feb. 20. 2019. Avaiable in http://www. fzb.rs.gov.br/conteudo/4809/?Homologada a nova Lista da Flora Ga $\% \mathrm{C} 3 \% \mathrm{BA}$ cha Am ea $\% \mathrm{C} 3 \% \mathrm{~A} 7 \mathrm{ada}$ de Extin $\% \mathrm{C} 3 \% \mathrm{~A} 7 \% \mathrm{C} 3 \% \mathrm{~A} 3 \mathrm{o}$.

Rivas M, RL Barbieri. 2014. Boas práticas em manejo para o extrativismo sustentável do Butiá. Brasília, Brasil. Embrapa. 50 p.

Schlindwein G. 2012. Implicações ecológicas da dormência de sementes em Butia odorata (Arecaceae). Tese de Douto- rado. Porto Alegre, Brasil. Universidade Federal do Rio Grande do Sul. 139 p.

Soares KP, SJ Longhi, L Witeck Neto, LC Assis. 2014. Palmeiras (Arecaceae) no Rio Grande do Sul, Brasil. Rodriguésia 65(1): 113-139. DOI: https://doi.org/10.1590/S217578602014000100009 .

Taiz L, T Zeiger, IM Moller, A Murphy. 2017. Fisiologia e desenvolvimento vegetal. Porto Alegre, Brasil. Artmed. 888 p.

Teixeira PC, HS Rodrigues, WAA Lima, RNC Rocha, RNV Cunha, R Lopes. 2009. Influência da disposição dos tubetes e da aplicação de fertilizantes de liberação lenta, durante o préviveiro, no crescimento de mudas de dendezeiro (Elaeis guineensis Jacq.). Ciência Florestal 19(2): 157-168. DOI: http://dx.doi.org/10.5902/19805098407.

Recibido: $21 / 04 / 20$

Aceptado: 08/06/20 
